Egyptian Journal of Aquatic Biology \& Fisheries

Zoology Department, Faculty of Science,

Ain Shams University, Cairo, Egypt.

ISSN 1110 - 6131 Vol. 22(1): 65- 73 (2018)

ejabf.journals.ekb.eg

Indexed in Scopus

\title{
Seasonal growth of Arabian scad Trachurus indicus from the Gulf of Suez, Red
} Sea, Egypt.

\author{
Sahar F. Mehanna ${ }^{1}$, Belal A. Soliman ${ }^{2}$, Mohamed A. Sayed. ${ }^{1}$ and \\ Rana Abdel Aliem ${ }^{1}$ \\ 1- Fisheries Division, National Institute of Oceanography and Fisheries, Egypt. \\ 2- Faculty of Science, Suez University, Suez, Egypt.
}

\section{ARTICLE INFO \\ Article History: \\ Received: Feb. 22, 2018 \\ Accepted: April 22, 2018 \\ Available online: May, 2018}

Keywords:

Trachurus indicus

Arabian scad

Growth

Gulf of Suez

Red Sea

Egypt

\begin{abstract}
Horse mackerel and scads, family Carangidae, are the most abundant pelagic fishes inhabiting the Gulf of Suez, Red Sea where they constituted about $77 \%$ of the total purse-seine catch in the Gulf. Growth of fish is a process that influenced by the environmental conditions especially temperature. Age and seasonal growth of Trachurus indicus were studied from samples collected randomly during the fishing season 2015/2016 from the Attaka port the main landing site in the Gulf of Suez. Otoliths of 1120 specimens were used for age determination and the maximum attained age for this species was three years. The seasonal length-weight relationship was investigated and the growth type was found to be greatly affected by environmental parameters in different seasons. The seasonal von Bertalanffy growth model was applied to estimate the seasonal growth parameters $L \infty, K$ and $t_{0}$. It is clear that temperature is a major factor affecting the Arabian scad growth.
\end{abstract}

\section{INTRODUCTION}

Movement, physiological processes and distribution of fishes are strongly influenced by environmental conditions, ecological constraints, and physical habitat characteristics. Like many organisms, fish respond to subtle changes in factors like temperature, dissolved oxygen, salinity, $\mathrm{pH}$, turbidity, and light. Growth is defined as a gradual increase in a living system in some quantity over time (Von Bertalanffy, 1934). Growth also defined as percentage increase in body dimension per time (Hopkins, 1992). Growth is a process, influenced by many internal and external factors that may be biotic or abiotic (Lugert et al., 2016). Biotic factors such as sex (Imsland and Jonassen, 2003), age (Von Bertalanffy, 1938; Deniel, 1990); and genetic variance; and abiotic factors such as water parameters especially temperature (Imsland et al., 2007), photoperiod (Imsland and Jonassen, 2003) and oxygen level (Lugert et al., 2016).

Horse mackerel (family: Carangidae) are the most dominant fish group not only in the catch of the Gulf of Suez but in the whole Egyptian Red Sea fisheries. Horse mackerel exploited mainly by purse-seine fishing method but a considerable amount was also caught by trawling as these species make a diurnal vertical migration. Arabian scad, Trachurus indicus is the most dominant carangid species in the Gulf of Suez. 
Considering that there are no studies on the seasonal growth and impact of temperature on the growth rate of Arabian scad in the Gulf of Suez, the present work is the first to investigate the seasonal growth rate of this fish species.

\section{MATERIALS AND METHODS}

\section{Sampling and water temperature}

A total of 1120 specimens $(9-21.5 \mathrm{~cm} \mathrm{TL})$ of $T$. indicus were collected randomly from the commercial catch of purse seine in the Gulf of Suez during the fishing season 2015/2016. The total length (TL) was measured to the nearest millimeter and the body weight (W) was recorded to the nearest gram. Sex was determined and otoliths were extracted, and kept clean in special envelopes with full details. Water temperature was recorded seasonally through the monitoring program of EEAA.

\section{Length-weight relationship}

The length-weight relationship in different seasons of $T$. indicus was described by the power function equation:

$$
\mathrm{W}=\mathrm{aL}^{\mathrm{b}}
$$

Where $\mathrm{a}$ and $\mathrm{b}$ are constants whose values were estimated by the least square method.

\section{Age determination}

For age determination, sagittal otoliths were prepared and examined. Otoliths were withdrawn carefully from the chambers of the inner ear of each fish and any adhering tissues were removed from the otolith by rubbing them gently between fingers under water. They were stored dry in special envelopes with full information for further reading. Annual rings on the whole otolith were counted in glycerin under a binuclear Stereomicroscope with reflected light.

\section{Von Bertalanffy (1938) growth parameters}

The von Bertalanffy model (1938) for seasonal growth was applied to determine the seasonal rate of growth of $T$. indicus. The growth model used in the analyses was the seasonally oscillating version of the von Bertalanffy growth function as proposed by Pauly and Gaschutz (1979). The model has the form:

Where:

$$
\mathrm{L}_{\mathrm{t}}=\mathrm{L} \infty\left(1-\mathrm{e}^{-[\mathrm{k}(\mathrm{t}-\mathrm{to})+\mathrm{ck} 2 \Pi \sin [2 \Pi(\mathrm{t}-\mathrm{ts})]}\right)
$$

$\mathrm{L}_{\mathrm{t}}=$ mean length at age $\mathrm{t}$.

$\mathrm{L}_{\infty}=$ asymptotic length, i.e. the (mean) length of a given stock would reach if they were left to grow forever.

$\mathrm{K}=$ growth coefficient that determines the rate at which $\mathrm{L}_{\infty}$ is attained.

$\mathrm{t}=$ age at length $\mathrm{L}_{\mathrm{t}}$.

$\mathrm{t}_{0}=$ age at which the length is theoretically equals zero.

$\mathrm{c}=$ the amplitude of seasonal growth oscillation.

ts $=$ the age at the beginning of growth oscillation

$\mathrm{WP}=$ winter point $(\mathrm{wp}=\mathrm{ts}+0.5)$ is the time of year when growth is slowest (Pauly, 1987).

\section{Growth Performance Index (Ø)}

According to Moreau et al., 1986 the following equation was used to estimate the growth performance of length for the species under study. Growth performance in length equation can be written as:

$$
\boldsymbol{\emptyset}_{\mathrm{L}}=\log \mathrm{K}+2\left(\log \mathbf{L}_{\infty}\right)
$$




\section{RESULTS AND DISCUSSION}

\section{Purse-Seine Fishery}

According to El-Gammal and Mehanna (2002) and Mehanna and El-Gammal (2007), the number of fishing boats varied between 56 and 83 vessel operated inside the Gulf. The vessel's length ranged between 12.5 and $30 \mathrm{~m}$. They are powered by engines of 150 to $600 \mathrm{hp}$ with the majority (63 vessels) of 400-600 hp. The purseseiners are operated at night using lighted dinghies. This illumination leads to concentrate the fish before setting the net. All fishing ceases during an approximately ten days during each month when the moon is full. The crew number ranged between 25 and 30 persons. The purse-seine fishery is seasonal generally from October through May. The purse-seine fishery contributed about $77.9 \%$ of the total fish production from the Gulf. This constitutes about $32 \%$ of the gross revenue of the Gulf.

Since 2015 and after the drop in purse seine catch, the fishing was banned from mid-April to the first September each year as well as 78 purse seiners was established in the Gulf (GAFRD, 2015).

The annual total catch in the Gulf of Suez fluctuated between a maximum values (19,382 ton) recorded during the fishing season 2009, and a minimum value (9,204 ton) recorded during the fishing season 2006, with an average value of 14,628 ton, throughout the past fifteen years. On the other hand, annual total purse seine catch fluctuated between a maximum value of 15,082 ton (representing $83 \%$ of the total Gulf catch), recorded during the fishing season 2001, and a minimum value of 4,974 ton (representing 33\%), recorded during the fishing season 2011, with a mean value of 9771 ton (representing 67\%), throughout the fifteen years ago.

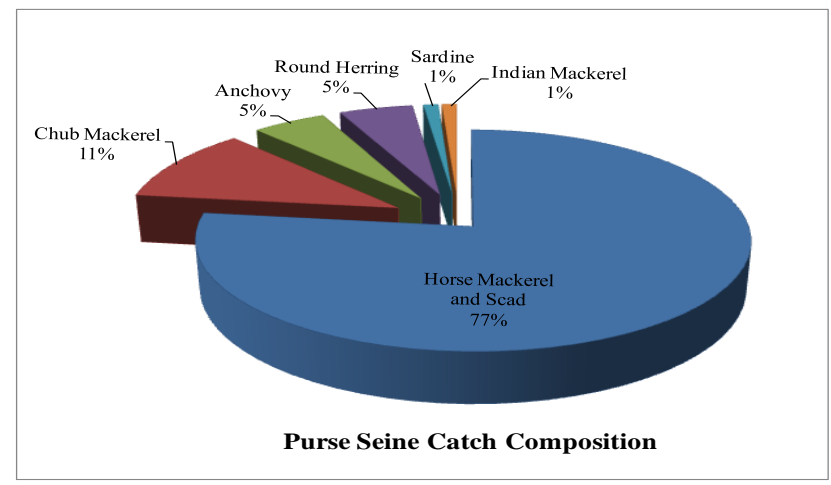

Fig. 1: Catch composition of purse seine fishery in the Gulf of Suez (GAFRD 2015)

The pelagic fish community of the Gulf includes representatives of the horse mackerel, scads and jacks (Family: Carangidae); anchovies (Engraulidae); sardine, round herring and Sardinella (Clupeidae); mackerels (Scombridae); barracudas (Sphyraenidae) and silversides (Atherinidae).

\section{Seasonal length and weight distribution:}

Length frequency distribution of Trachurus indicus, during the three seasons is given in Fig (2) to show the prevailing sizes of these fishes in the catch. A total of 1120 specimens of $T$. indicus (mid lengths $9.5-21.5 \mathrm{~cm}$ TL) were distributed along the seasons as 369, 372 and 379 specimens during autumn, winter and spring respectively. The frequency distribution of each length interval of the collected fish specimens showed that the bulk of the specimens fall at mid lengths from 12.5 to 17.5 $\mathrm{cm}$ TL. The average total length of males, females and sexes combined of $T$. indicus 
were 13.6, 14.4 and $13.6 \mathrm{~cm}$ at autumn season, 15.7, 13.6 and $14.8 \mathrm{~cm}$ at winter season and 13.6, 13.5 and $13.5 \mathrm{~cm}$ at spring season respectively. The average total weight was 30.8, 27.7 and $27.6 \mathrm{~g}$ at autumn season respectively; 43.0, 39.5 and $39.5 \mathrm{~g}$ at winter season and 28.9, 25.2 and $25.2 \mathrm{~g}$ at spring season (Table 1 and Fig. 3).

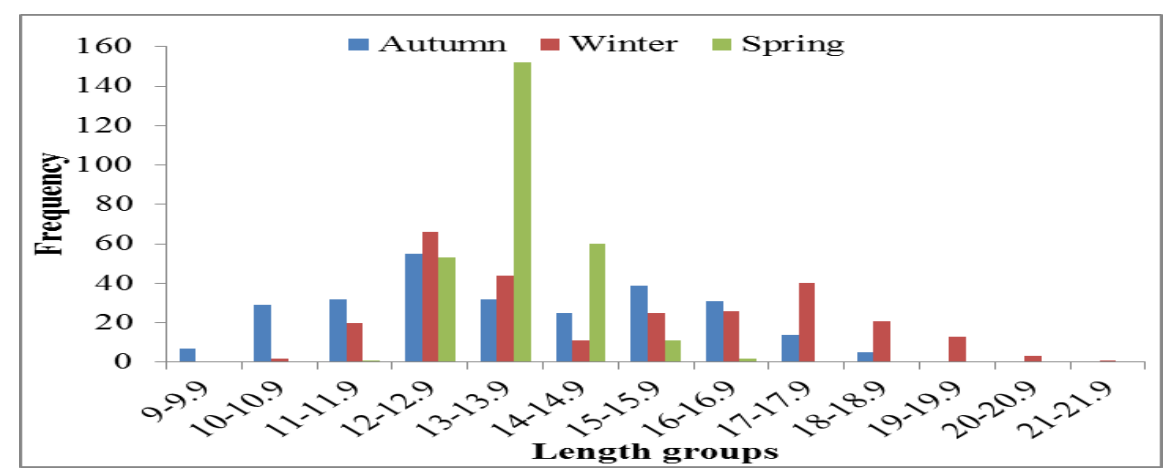

Fig. 2: Seasonal length distribution of Trachurus indicus in the Gulf of Suez.

Table 1: Seasonal average and standard deviation of total length (TL) and total weight (TW) of male $(\mathrm{M})$, female $(\mathrm{F})$ and combined sexes $(\mathrm{M} \& \mathrm{~F})$ of Arabian scad.

\begin{tabular}{|c|c|c|c|c|c|c|}
\hline Season & Sex & \multirow{2}{*}{ No. } & \multicolumn{2}{|c|}{ TL } & \multicolumn{2}{|c|}{ TW } \\
\cline { 4 - 7 } & & & Ave. & \pm St.d. & Ave. & \pm St.d. \\
\hline \multirow{3}{*}{ Autumn } & $\mathrm{M}$ & 72 & 13.6 & 2.2 & 30.8 & 12.7 \\
\cline { 2 - 7 } & $\mathrm{F}$ & 123 & 14.4 & 2.0 & 35.2 & 11.8 \\
\cline { 2 - 7 } & $\mathrm{M} \& \mathrm{~F}$ & 273 & 13.6 & 2.2 & 30.3 & 13.0 \\
\hline \multirow{3}{*}{ Winter } & $\mathrm{M}$ & 166 & 15.7 & 2.5 & 43.0 & 17.6 \\
\cline { 2 - 7 } & $\mathrm{F}$ & 122 & 13.6 & 1.8 & 29.3 & 12.1 \\
\cline { 2 - 7 } & $\mathrm{M} \& \mathrm{~F}$ & 291 & 14.8 & 2.5 & 37.0 & 17.0 \\
\hline \multirow{3}{*}{ Spring } & $\mathrm{M}$ & 150 & 13.6 & 0.7 & 28.9 & 4.9 \\
\cline { 2 - 7 } & $\mathrm{F}$ & 129 & 13.5 & 0.8 & 28.0 & 5.3 \\
\cline { 2 - 7 } & $\mathrm{M} \& \mathrm{~F}$ & 280 & 13.5 & 0.7 & 28.5 & 5.1 \\
\hline
\end{tabular}



Fig. 3: Seasonal average length and standard deviation of males (M), females (F) and combined sexes $(\mathrm{M} \& \mathrm{~F})$ of Arabian scad

\section{Length weight relationship}

The length and weight measurements of 1120 specimens of T. indicus; 369 individual in autumn with total Length range $9-18.9 \mathrm{~cm} \&$ weights $9.6-61.21 \mathrm{~g}, 372$ individual in winter of length range $10-21.9 \mathrm{~cm}$ and weight range $11.9-90.7 \mathrm{~g}$ and 379 individual in spring of length range $11-16.9 \mathrm{~cm}$ and weight range $18-45.4 \mathrm{~g}$ were used for the estimation of length weight relationship (Figs. 4\& 5).

The estimated total length - body weight equations, for males, females and sexes combined of the Arabian scad in different seasons are given in Table (2) and the constants of these relations are summarized in Table (3).

It was found that the type of growth is changed from season to another, while the growth type was negative allometric in autumn and winter, it was isometric in spring. This trend was noticed for males, females and sexes combined. 



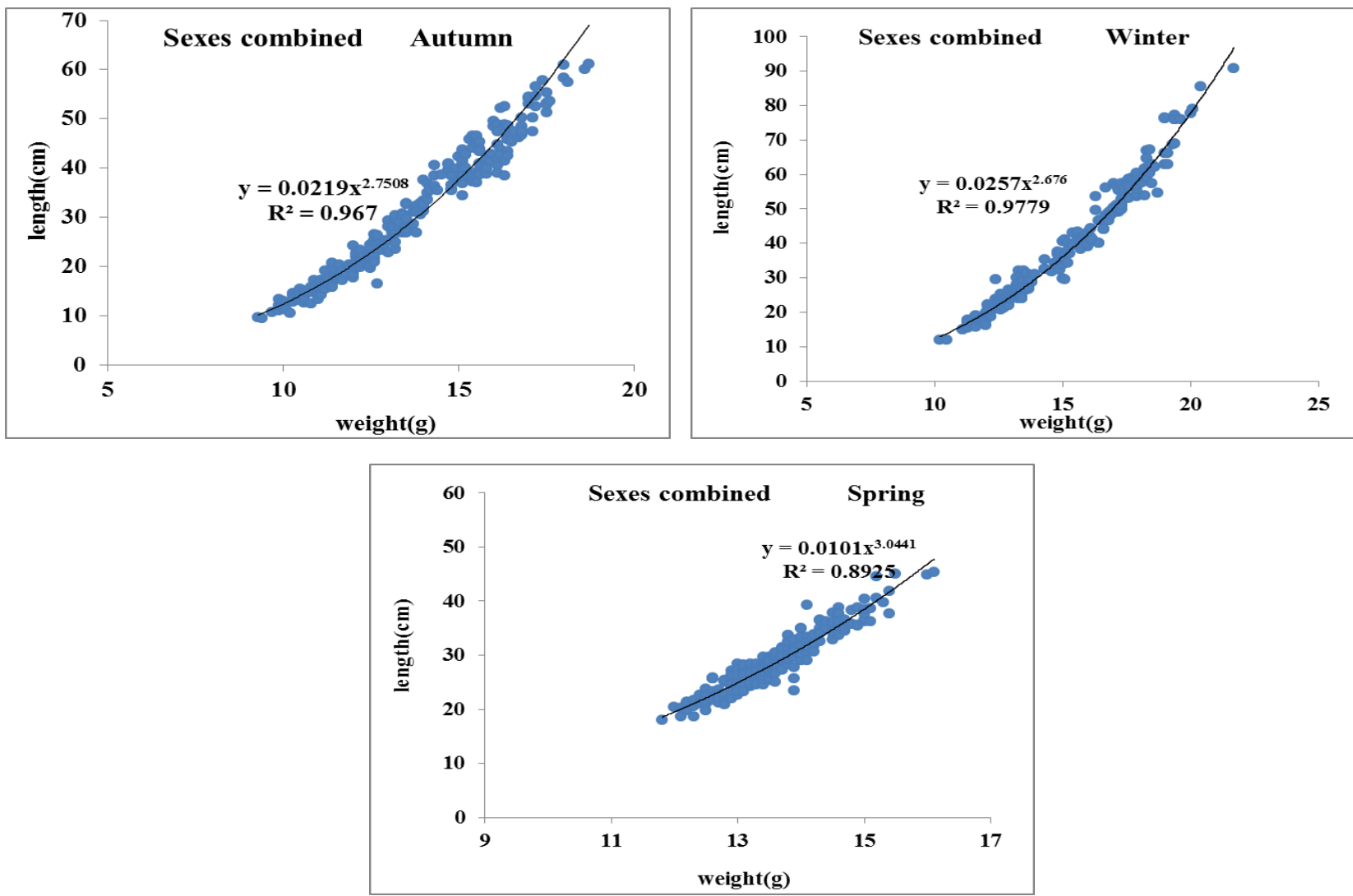

Fig. 4: Seasonal Length - weight relationship of Arabian scad from the Gulf of Suez.
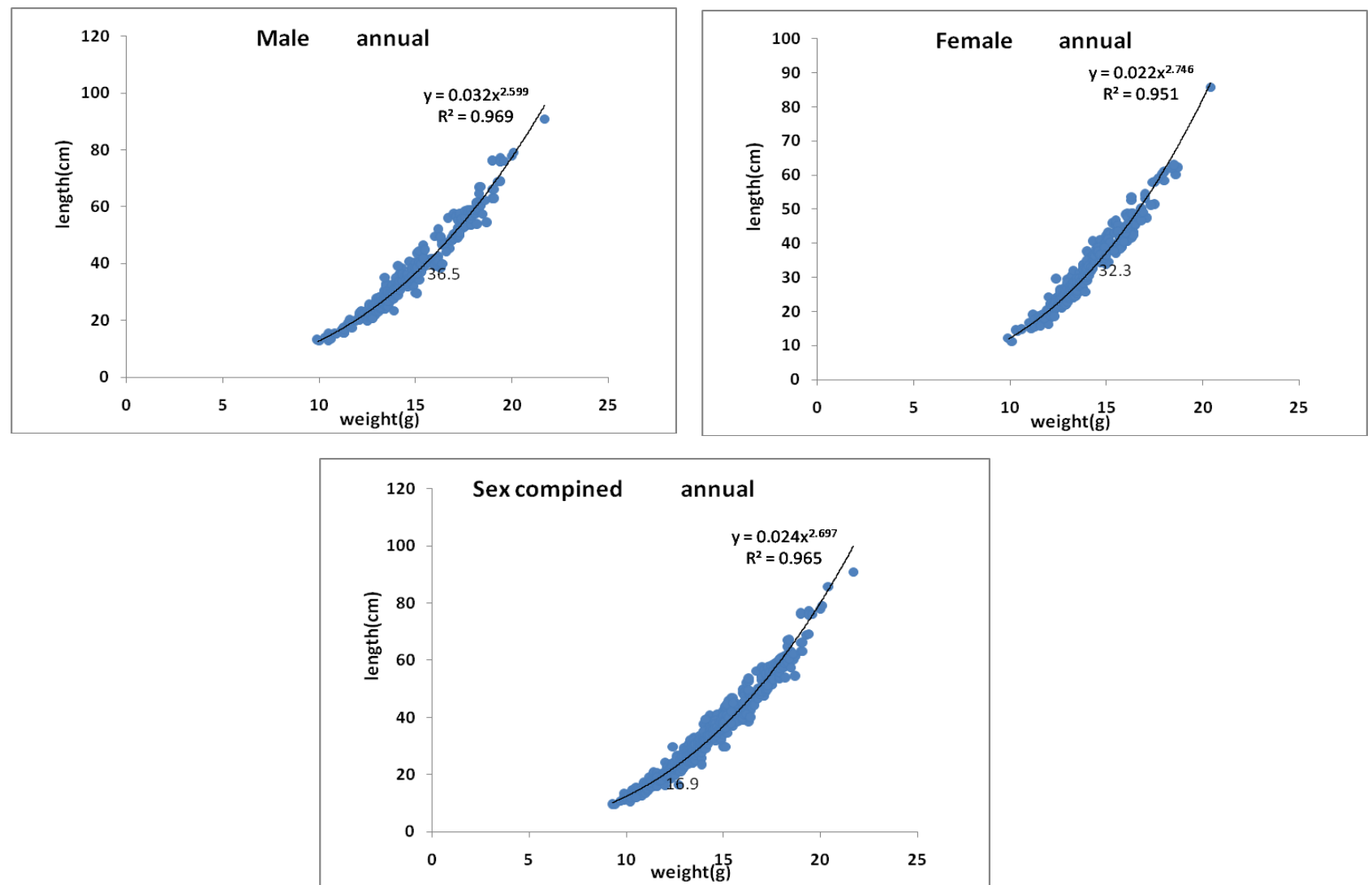

Fig. 5: Annual Length - weight relationship of Arabian scad from the Gulf of Suez 
Table 2: Seasonal length-weight relationship of Trachurus indicus in the Gulf of Suez.

\begin{tabular}{|c|c|}
\hline Season and sex & Length-Weight Equations \\
\hline Autumn & $\mathrm{W}=0.0283 \mathrm{TL}^{2.6582}$ \\
Male & $\mathrm{W}=0.0327 \mathrm{TL}^{2.606}$ \\
Female & $\mathrm{W}=0.0219 \mathrm{TL}^{2.7508}$ \\
Sexes combined & $\mathrm{W}=0.028 \mathrm{TL}^{2.6377}$ \\
\hline Winter & $\mathrm{W}=0.019 \mathrm{TL}^{2.7818}$ \\
Male & $\mathrm{W}=0.0257 \mathrm{TL}^{2.676}$ \\
Female & $\mathrm{W}=0.0103 \mathrm{TL}^{3.037}$ \\
Sexes combined & $\mathrm{W}=0.0104 \mathrm{TL}^{3.0353}$ \\
\hline Spring & $\mathrm{W}=0.0101 \mathrm{TL}^{3.0441}$ \\
Male & \\
Female & $\mathrm{W}=0.032 \mathrm{TL}^{2.599}$ \\
Sexes combined & $\mathrm{W}=0.022 \mathrm{TL}^{2.746}$ \\
Whole fishing year & $\mathrm{W}=0.024 \mathrm{TL}^{2.697}$ \\
Male & Female \\
Sexes combined &
\end{tabular}

\section{Age Determination}

In fisheries science, the age of harvested individuals is one of the most important parameters for the assessment and management of commercially exploited stocks. The determination of age and growth is of great importance to both fisheries biology and management as it provides information pertaining to the growth rate. In addition, it forms the basic knowledge required for the estimation of mortality, recruitment and yield. These parameters constitute the basic information needed for the construction of a management strategy for any exploited stock (Mehanna, 1996).

Sagittal otoliths were used for age determination of Arabian scad T. indicus in the present work. The total life span of this species was three years for length range from 9 to $21.7 \mathrm{~cm}$ TL.

El-Gammal et al. (1995) found that the life span of males and females of $T$. indicus in Gulf of Suez was four and three years, respectively. The average back calculated lengths for the corresponding ages were comparable with those of the present study. The difference in longevity may be attributed to the sample size that covered a limited length interval, from 9 to $17.9 \mathrm{~cm}$, i.e. the sample didn't include large fishes. On the other hand, the findings of Mehanna (1999) concerning age and growth of the same species in the Gulf were relatively similar to those of the present study.

\section{Growth Parameters and Growth Performance Index}

Growth of fish can be defined in various ways, but is usually measured as the change in weight or length over a period of time.

The influence of temperature on growth of the Arabian scad stock in the Gulf of Suez has been analyzed by applying the seasonal growth model of von Bertalanffy. It is clear that temperature is a major factor affecting the Arabian scad growth. Most species of fish in the juvenile stages show a rapid increase in specific growth rate as temperature increases passing through a peak $\left(\mathrm{T}_{\mathrm{opt}} \cdot \mathrm{G}\right)$ and then falling rapidly as high temperatures become adverse (Brett, 1979; Martinez et al., 1996; Nytro, 2013).

As temperature is among the most important environmental factors determining growth of fish, it is important for farmers to know the optimal temperature for growth ( $\left.\mathrm{T}_{\mathrm{opt}} \mathrm{G}\right)$. Optimal temperature for growth of a given fish species is, however, not readily identified, as it changes with size, and many factors such as food intake, photoperiod, salinity, body condition, and oxygen saturation may affect the relationship between temperature and growth (Brett, 1979; Lushchak and 
Bagnyukova, 2006). The obtained values of asymptotic length $\mathrm{L}_{\infty}$ for $T$. indicus, was $20.55,24.47,18.35$ and $25.06 \mathrm{~cm}$ for autumn, winter, spring and whole fishing year respectively. On the other hand, the obtained results of $\mathrm{K}$ values were $0.60,0.57,0.75$ and 0.53 / year for autumn, winter, spring and whole fishing year respectively.

The asymptotic weights $\left(\mathrm{W}_{\infty}\right)$ obtained from the asymptotic lengths $\left(\mathrm{L}_{\infty}\right)$ are $89.48,133.63,70.95$ and $142.32 \mathrm{~g}$, for autumn, winter, spring and whole fishing year respectively.

It is clear that the growth parameters are greatly affected by the environmental conditions especially the temperature.

No previous estimates of $\mathrm{L}_{\infty}, \mathrm{K}$ and $\mathrm{W}_{\infty}$ have been done seasonally for $T$. indicus. On the other hand, the obtained values of $\mathrm{L}_{\infty}, \mathrm{K}$ and $\mathrm{W}_{\infty}$ of the whole year for the investigated species; T. indicus, in the Gulf of Suez, did not show much difference when compared to the $\mathrm{L} \infty, \mathrm{K}$, and $\mathrm{W}_{\infty}$ values estimated by the other authors for the same species in the Gulf of Suez. El-Gammal et al. (1995) gave the following values for the growth parameters of T. indicus from the Gulf of Suez; K = 0.28 /year, $\mathrm{L}_{\infty}=20.3 \mathrm{~cm}$ and $\mathrm{t}_{0}=-1.64$ year. The growth parameters of $T$. indicus were estimated by Mehanna (1999) as $\mathrm{K}=0.43$ /year, $\mathrm{L}_{\infty}=24.36 \mathrm{~cm} \mathrm{TL}, \mathrm{W}_{\infty}=$ $132.213 \mathrm{~g}$ and $\mathrm{t}_{0}=-0.41$ year for males and $\mathrm{K}=0.5 /$ year, $\mathrm{L}_{\infty}=23.48 \mathrm{~cm} \mathrm{TL}, \mathrm{W}_{\infty}=$ $135.941 \mathrm{~g}$ and $\mathrm{t}_{0}=-0.30$ year for females.

The computed Growth performance Index $\left(\varnothing^{\prime}\right)$ for $T$. indicus was 2.40, 2.53, 2.40, and 2.52 for autumn, winter, spring and whole fishing year respectively.

In conclusion, the environmental conditions especially the water temperature are greatly affected the physiological processes and behavior of fishes. So, they should be considered when the growth and the life history of fish stocks were studied.

\section{REFERENCES}

Brett, J. R. (1979): Environmental Factors and Growth. In: Hoar WS, Randall DJ, Brett JR (eds) Fish Physiology, Vol. 8, Academic Press, New York. 599 - 675.

Deniel, C. (1990): Comparative study of growth of flatfishes on the west coast of Brittany. Journal of Fish Biology., 37: 149-166.

EEAA annual report (2016): Environmental information monitoring program (EIMP) of coastal water of Red Sea proper, Gulf of Suez and Gulf of Aqabq" 2016.

El-Gammal, F. I.; Bebars, M. I. and Tharwat, A. (1995): Age, growth and mortality of horse mackerel, Trachurus indicus from the Gulf of Suez. J. Appl. Sci., 10(3): 420-430.

El-Gammal, F. I. and Mehanna, S. F. (2002): Purse-seine fishery in the Gulf of Suez with special reference to sardine fishery. Asian J. Fish.15 (1): 81-88.

El-Sherbeny, A. (2015): Application of Remote Sensing Techniques, Geographical Information Systems and Analytical Models, for the Pelagic Fisheries Management in the Gulf of Suez, Egypt. Ph.D., Thesis, Ain Shams University, Egypt.

GAFRD (2015). General Authority for Fish Resources Development. Annual book of fisheries statistics of Egypt, 2015.

Hopkins, K.D. (1992): Reporting fish growth, a review of the basics. Journal of World Aquaculture Society, 23: 173-179.

Imsland, A.K. and Jonassen, T.M. (2003): Growth and age at first maturity in turbot and halibut reared under different photoperiods. Aquaculture International, 11: 463-475. 
Imsland, A.K.; Schram, E.; Roth, B.; Schelvis-Smit, R. and Kloet, K. (2007): Growth of juvenile turbot Scophthalmus maximus (Rafinesque) under a constant and switched temperature regime. Aquaculture International, 15: 403-407.

Lugert, V.; Thaller, G.; Tetens, J.; Schulz,C. and Krieter, J.(2016): A review on fish growth calculation: multiple functions in fish production and their specific application. Reviews in Aquaculture, 8: 30-42.

Lushchak, V.I. and Bagnyukova, T.V. (2006): Effects of different environmental oxygen levels on free radical processes in fish. Comp. Biochem. Physiol., B 144: 283-289.

Martinez, C.A.P.; Cristina, C.S. and Ross, L.G. (1996): The effects of water temperature on food intake, growth and body composition of Cichlasoma urophthalmus (Güter) juveniles. Aquaculture Research., 27 ( 6): 455-461.

Mehanna, S. F. (1996): A biological and dynamical study on fish population of Lethrinus mahsena in Gulf of Suez, Egypt. Ph.D. Thesis. Faculty of science. Zagazig University. Benha branch. Egypt.

Mehanna, S. F. (1999): Stock assessment of the horse mackerel Trachurus indicus in the Gulf of Suez, Egypt. Indian J. of Fisheries, 46 (4): 327-335.

Mehanna, S.F. and El-Gammal F.I. (2007): Gulf of Suez Fisheries: Current Status, Assessment and Management. JKAU: Mar. Sci., 18:3-18.

Nytrø, A.V. (2013): The effect of temperature and fish size on growth of juvenile lumpfish (Cyclopterus lumpus L). Master's Degree Thesis in Fisheries Science Field of Study - Aquaculture Biology.

Von Bertalanffy, L. (1934): Untersuchungen €uber die Gesetzlichkeit des Wachstums I. Wilhelm Roux’ Arch. EntwMech. Org., 131: 613-653.

Von Bertalanffy, L. (1938): A quantitative theory of organic growth (Inquiries on growth laws II). Human Biology, 10: 181-213.

\section{ARABIC SUMMARY}

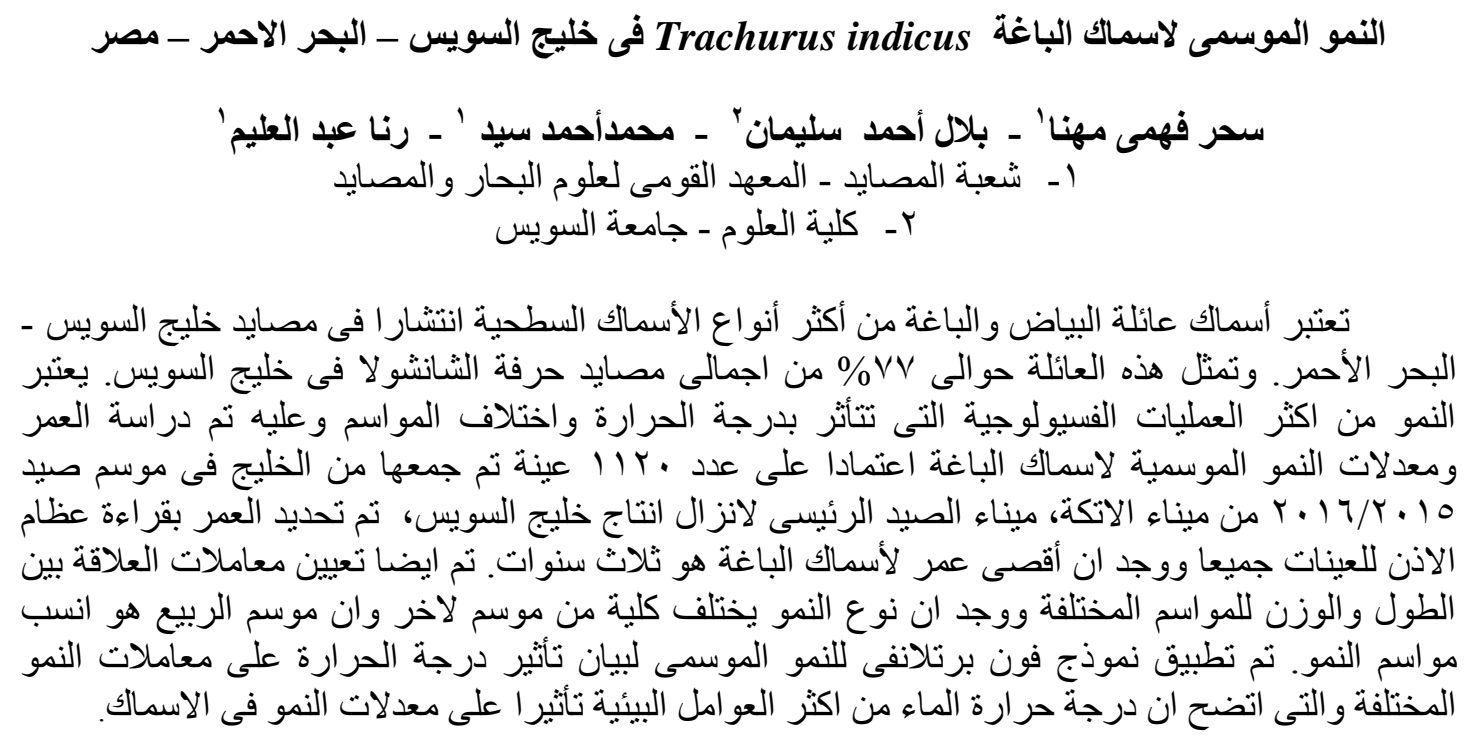

